\title{
Reservoir properties and facies characterization from core data and well logging: autochthonous Miocene sediments in the Carpathian Foredeep case study
}

\author{
Ali Shouket ${ }^{1}$, Jadwiga Jarzyna ${ }^{2}$ \\ ${ }^{1}$ Bahria University, Department of Earth and Environmental Sciences; Islamabad, Pakistan; \\ e-mail: shaukataligeologist@gmail.com \\ ${ }^{2}$ AGH University of Sciences and Technology, Faculty of Geology Geophysics and Environment Protection, Department \\ of Geophysics; al. Mickiewicza 30, 30-059 Krakow, Poland; e-mail: jarzyna@agh.edu.pl (corresponding author)
}

(C) 2014 Authors. This is an open access publication, which can be used, distributed and reproduced in any medium according to the Creative Commons CC-BY 4.0 License requiring that the original work has been properly cited.

Received: 30 January 2015; accepted: 2 March 2015

\begin{abstract}
Laboratory results of total porosity and physical permeability were the basis to calculate Flow Zone Indicator. GR log and porosity log PHI were used for facies identification. Calculations and loggings were performed in the Miocene sandy-shaly sediments in two wells in the Eastern Part of Polish Carpathian Foredeep. FZI increase with the total porosity from the comprehensive interpretation of logs in the regressive set of parasequences was observed. This increase was the result of better reservoir and hydraulic abilities of these parasequences in comparison to transgressive ones. Combining information of laboratory origin with well logging results on the basis of facies and FZI correlation worked also as a kind of data scaling.
\end{abstract}

Keywords: porosity, permeability, Flow Zone Indicator, facies, parasequences, regression and transgression sedimentary systems

\section{INTRODUCTION}

The study was undertaken to show a relationship which exist between facies, depositional environment and reservoir properties. This relationship can be determined accurately from analysis of well logs (Basham \& Dorfam 1983). Facies and depositional environment determination are the fundamental work carried out when clastic reservoir are studied for the purposes of hydrocarbon exploration and development. The occurrence of reservoir quality strata in different rock types is related to the distribution of rock facies which in turn reflects the environment of deposition. Currently, depositional facies distribution is determined from geologic analysis of laboratory and well logging data (Samadi et al. 2006, Bingjian et al. 2011). The presented case study was aimed to show that in monotonous sandy-shaly thin-bedded Miocene formation combination of reservoir properties with facies distribution can be helpful in prospecting small gas accumulations.

\section{GEOLOGICAL SETTING}

The Sarmatian sediments are the main gas-saturated series in the Polish part of the Carpathian Foredeep (Myśliwiec 2004a, 2004b). Gas reservoirs mainly occur in sandstones and heterolithes of deltaic banks, turbidites of deltaic fronts, prodeltas or submarine fans as well as in shallow shelf and estuary deposits. The Miocene reservoir rocks 
of the Carpathian Foredeep are almost exclusively sandy-shaly sediments but of great variety of reservoir properties depending on sedimentation environment. Deltaic deposits and submarine fans sediments are classified as the best gas reservoirs. Sandy sediments of submarine fans dominate in the south part of the Carpathian Foredeep, however to the north they are replaced with fine-grained deposits. In the north in the upper part of geological profile deltaic sediments predominate (Myśliwiec 2004a).

\section{Deltaic deposits}

The main features of the deltaic deposits which can be well recognized in well logs are sandy -shaly lithology and cyclicity in the vertical geological profile. In the deltaic deposits sandstone reservoirs occur simultaneously with sealing rocks as well as organic matter, being the hydrocarbon source (Myśliwiec 2004a, 2004b). Sediments in progradation system of the deltaic depositional environment comprise sets of layers composed of coarse grains with thickness increasing upwards. These sediments were formed as complex parasequences. They reveal complicated inner structure depending on different elements of sedimentary subenvironments (deltaic slope, deltaic platform and estuary bars). Sandstone layers in parasequences form almost homogeneous packets and the rest of the profile is built of sandstone and mudstone thin beds. Deltaic sandstones may be classified as lithic or sublithic wackes and in the case of good sorting as sublithic arenites. Sandstone heterolithes usually occur at the bottom of the sets of sandstone beds of horizontal bedding (Mastalerz et al. 2006).

\section{Shallow shelf deposits}

Shallow marine deposits are poorly sorted and reveal higher volume of fine grained clay-silt sediments. Bedding, typical for deltaic deposits is not so distinct in that case as well as vertical cyclicity is not recognized. Estuary bars and sandy barriers marking off lagoons were recognized as gas reservoirs. Gas was also found in mudstones composing interbedded structures with fine- and very finegrained sandstones (Myśliwiec 2004a, 2004b). The horizontal lamination dominated in mudstones and mudstone heterolithes.

\section{WELL LOGGING AND LABORATORY DATA}

Gas deposit S (rectangle in Figure 1) in the eastern part of the Polish Carpathian Foredeep was selected as a study area. Complete sets of well logs and results of laboratory measurements were available in two boreholes (S 33k and S 34) (Tab. 1). Research dedicated to combine facies recognized on the basis of well logs and hydraulic parameters of reservoir rocks represented by Flow Zone Indicator (FZI) calculated on the basis of laboratory measurements was realized in depth sections related to the Miocene Sarmatian and Upper Badenian deposits in both wells.

Authors used the results of laboratory measurements of $\mathrm{F}_{\text {tot }}$ - total porosity from helium pycnometer and $d_{b}$ - bulk density and $\mathrm{K}$ - absolute permeability from permeameter and also results of NMR laboratory experiments: Kp nmr tot NMR total porosity and Kp nmr ef - NMR effective porosity.

The following well logs were used:

- GR - natural gamma radioactivity as a result of logging (GR) and corrected for borehole influence (GRC),

- RHOB - bulk density from gamma-gamma log, - PHI - total porosity as the result of the comprehensive interpretation of well logs.

\section{Laboratory measurements results as indicators of rocks reservoir properties}

Laboratory results of total porosity, $\mathrm{F}_{\text {tot }}$ and absolute permeability, K from S34 well were the basis for determination of the relationship between $\log \mathrm{K}$ vs. total porosity for the full data set (Fig. 2). Correlation line is presented and determination coefficient is calculated, $R^{2}=0.76$ (Tab. 2). Correlation coefficient, $R=0.87$ is good but the distinct dispersion of data is observable. That is very frequent situation for geological data sets, especially in sandy-shaly thin-bedded formation in the discussed case. In the next step Flow Zone Indicator, FZI was calculated on the basis of the same data (Fig. 3). FZI was determined according to equation (1) following the Amaefule et al. (1993) and Ha Quang \& Jarzyna (2013) considerations and on the basis of the theoretical Kozeny-Carman formula (Kozeny 1927, Carman 1937). 


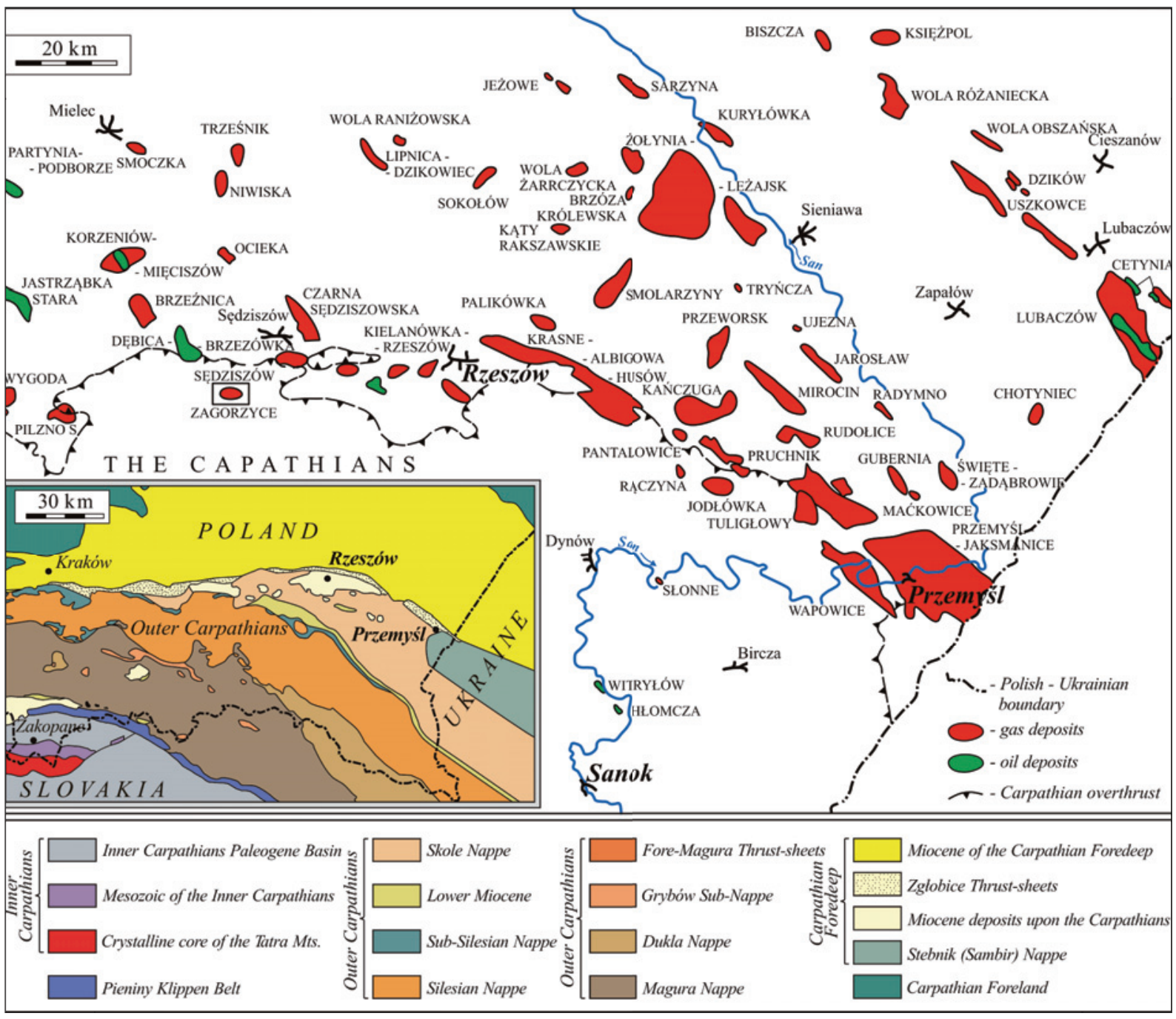

Fig. 1. Gas deposits in the Eastern part of the Polish Carpathian Foredeep. Selected gas deposits - red areas, S deposit - small rectangle, Carpathian Overthrust - black line (after Myśliwiec 2004a, after Bała et al. 2012)

Table 1

Geological and well logging data

\begin{tabular}{|c|c|c|c|c|c|c|c|}
\hline Well & Stratigraphy & Lithology & $\begin{array}{c}\text { Depth } \\
{[\mathbf{m}]}\end{array}$ & $\begin{array}{l}\text { Depth } \\
\text { interval of lab } \\
\text { results } \\
{[\mathrm{m}]}\end{array}$ & $\begin{array}{c}\text { Number } \\
\text { of } \\
\text { samples }\end{array}$ & $\begin{array}{l}\text { Used } \\
\text { laboratory } \\
\text { results }\end{array}$ & Used logs \\
\hline S 33k & $\begin{array}{c}\text { Miocene (Sarmatian } \\
\text { and Upper } \\
\text { Badenian) }\end{array}$ & $\begin{array}{l}\text { shales, } \\
\text { mudstones, } \\
\text { sandstones }\end{array}$ & $1350-2874$ & $2466.0-2566.5$ & 26 & \multirow{3}{*}{$\begin{array}{c}\mathrm{F}_{\text {tot }}, \mathrm{F}_{\mathrm{ef}}, \mathrm{K}, \\
\mathrm{Kp} \text { nmr tot, } \\
\text { Kp nmr ef, } \mathrm{d}_{\mathrm{b}}\end{array}$} & \multirow{3}{*}{$\begin{array}{l}\text { GR, GRC, } \\
\text { PHI, } \\
\text { RHOB }\end{array}$} \\
\hline \multirow[b]{2}{*}{ S 34} & $\begin{array}{c}\text { Miocene } \\
\text { (Sarmatian) }\end{array}$ & $\begin{array}{c}\text { siliciclastic } \\
\text { series }\end{array}$ & $996-1549$ & \multirow[b]{2}{*}{$1957.0-2602.5$} & \multirow[b]{2}{*}{23} & & \\
\hline & $\begin{array}{c}\text { Miocene (Upper } \\
\text { Badenian) }\end{array}$ & $\begin{array}{l}\text { claystones, } \\
\text { siliceous shales, } \\
\text { anhydrites }\end{array}$ & 2928 & & & & \\
\hline
\end{tabular}

Explanations: $\mathrm{F}_{\text {tot }}$ - total porosity, $\mathrm{F}_{\text {ef }}$ - effective porosity, $\mathrm{K}$ - absolute permeability, Kp nmr tot - NMR total porosity, Kp nmr ef - NMR effective porosity, $\mathrm{d}_{\mathrm{b}}$ - bulk density, GR - gamma ray log, GRC - borehole corrected gamma ray log, PHI - total porosity from the comprehensive interpretation, RHOB - bulk density from gamma-gamma log. 


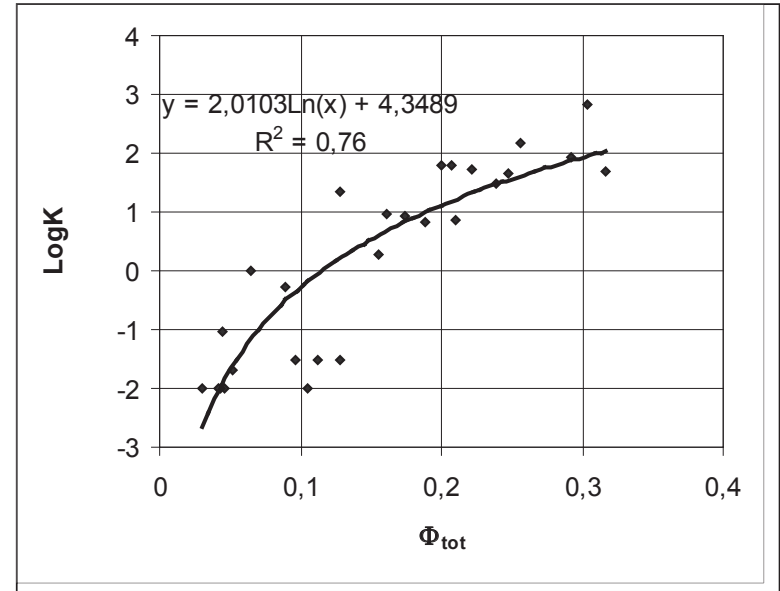

Fig. 2. Relationship between logarithm of permeability vs. total porosity; laboratory data

\section{Table 2}

Relationships between $\log K v$ s. total porosity (data from lab); correlation equations and determination coefficients (related to Figure 3)

\begin{tabular}{|l|c|c|}
\hline $\begin{array}{c}\text { Subsets } \\
\text { according to } \\
\text { FZI }\end{array}$ & Equation & $\begin{array}{c}\text { Determi- } \\
\text { nation } \\
\text { coefficient, } \\
\boldsymbol{R}^{2}\end{array}$ \\
\hline $3.1<\mathrm{FZI}<4.0$ & $y=1.3607 \operatorname{Ln}(x)+4.2989$ & 0.98 \\
\hline $2.1<\mathrm{FZI}<3.0$ & $y=1.5379 \operatorname{Ln}(x)+4.3896$ & 0.97 \\
\hline $1.2<\mathrm{FZI}<2.0$ & $y=1.5897 \operatorname{Ln}(x)+4.068$ & 0.92 \\
\hline $0.5<\mathrm{FZI}<1.1$ & $y=1.5338 \operatorname{Ln}(x)+3.6427$ & 0.94 \\
\hline FZI $<0.5$ & $y=0.4516 \operatorname{Ln}(x)-0.4922$ & 0.86 \\
\hline Total set of data & $y=2.0103 \operatorname{Ln}(x)+4.3489$ & 0.76 \\
\hline
\end{tabular}

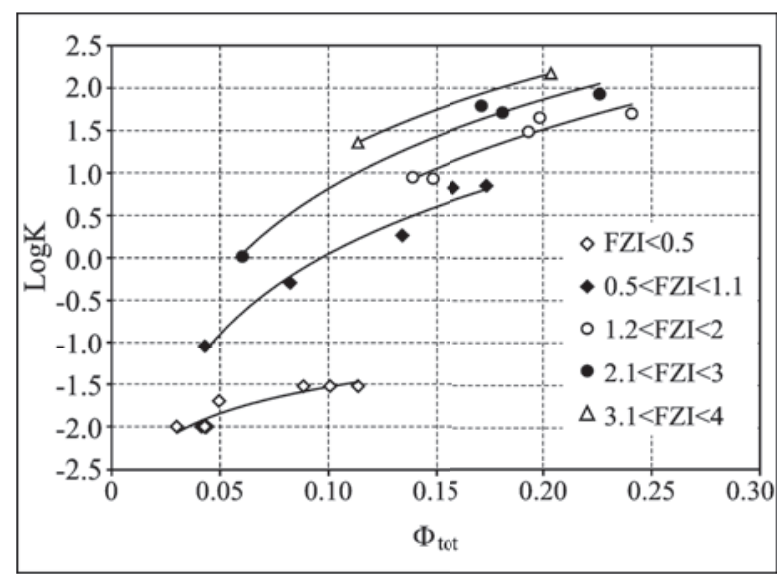

Fig. 3. Relationship between logarithm of permeability vs. total porosity; laboratory data; subsets defined on the basis of FZI
The concept of Flow Zone Indicator, i.e. factor characterizing the hydraulic flow units combines only porosity and permeability and includes influence on the latter not only porosity, but also pore space geometry, grain size distribution, specific surface area of pores, tortuosity, fluid saturation and other properties included indirectly in the Kozeny-Carman equation. It is a unique and useful value to quantify the hydraulic character of reservoir. FZI can be calculated on the basis of reservoir properties from small-scale data obtained from core plugs and large-scale from well logs:

$$
\mathrm{FZI}=0.0314 \sqrt{K / \Phi_{e}} \cdot \frac{1-\Phi_{e}}{\Phi_{e}}
$$

where:

FZI - Flow Zone Indicator $[\mu \mathrm{m}]$,

$K$ - absolute permeability $[\mathrm{mD}]$,

$\Phi_{e}-$ effective porosity [frac.].

Correlations between LogK vs. $\mathrm{F}_{\text {tot }}$ were calculated for subsets selected relating to FZI. The determination coefficients calculated for individual subsets were higher than for the full data set (Tab. 2). The correlation lines in Figure 3 are almost parallel, what confirms that the division of full data set into subsets was well done. Only, the first subset (FZI < 0.5 ) revealed correlation line not parallel to others. Determination coefficient in this case is relatively low $\left(R^{2}=0.86\right)$ but still higher than for full data set $\left(R^{2}=0.76\right)$. FZI in this range was calculated on the basis of the lowest $\mathrm{K}$, just close to $0.01 \mathrm{mD}$. This value is the lower border of permeability measurement.

Similar results for FZI were obtained for calculation using total porosity from laboratory NMR measurements.

FZI ranged from very low values, lower than 0.25 , to pretty high values. The highest FZI calculated on the basis of pycnometer total porosity $\left(\mathrm{F}_{\text {tot }}\right)$ equaled to $5.47 \mu \mathrm{m}$. the highest FZI value calculated on the basis of NMR total porosity equaled to $7.44 \mu \mathrm{m}$. The sample revealing the highest FZI had also the highest absolute permeability. $\mathrm{K}=652.35 \mathrm{mD}$. When effective porosity from laboratory NMR measurements were used, FZI reached even value equal to $113 \mu \mathrm{m}$. where effective porosity was extremely low $(\mathrm{Kp} \mathrm{nmr} \mathrm{ef}=0.19 \%)$ and permeability was also low $(\mathrm{K}=0.09 \mathrm{mD})$. Two relationships (Figs 4 and 5) presented good correlation between total porosity from laboratory pycnometer measurements, $\Phi$ por lab and from NMR 
experiments, $\Phi$ tot nmr and correlation between FZI calculated from $\Phi$ por lab vs. FZI calculated from $\Phi$ tot nmr. Changes in porosity are reflected in FZI.

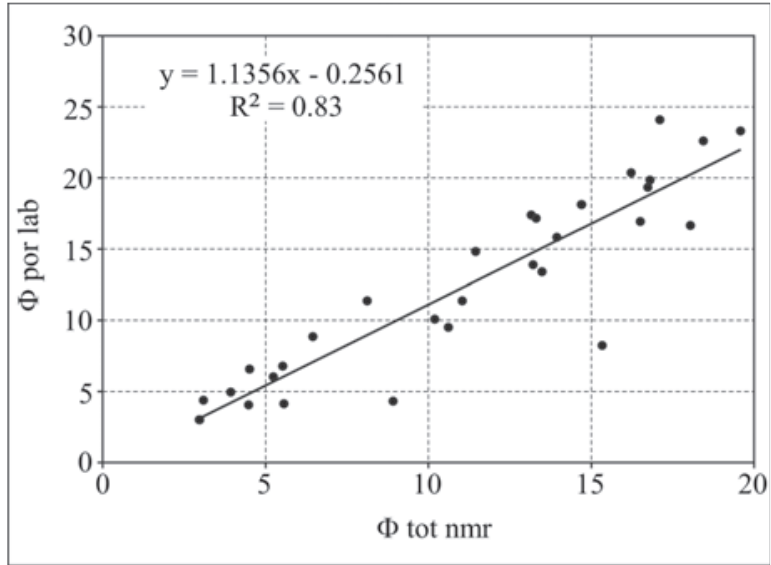

Fig. 4. Relationship between helium pycnometer porosity and NMR experiment

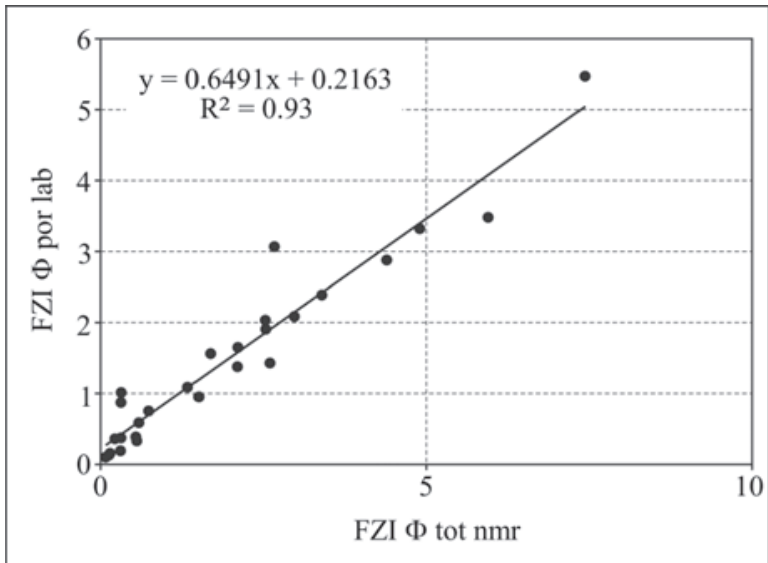

Fig. 5. Relationships between FZI calculated on the basis of helium pycnometer porosity and NMR porosity

In the next step, laboratory data were combined with well logging results. RHOB (from gamma-gamma log) and PHI (from the comprehensive interpretation) were read applying the depth criterion and matched to the depths of all core plugs used in laboratory measurements. Because of various vertical resolution of well logs and due to the almost point information from core plugs the depth matching (shifting in the depth) of PHI and RHOB was made. Final result of depth matching was presented as correlation between PHI and PHI read from shifted depth (Fig. 6). Relationship between total porosity and bulk density from laboratory well logging data also confirmed proper depth ascribing (Fig. 7).

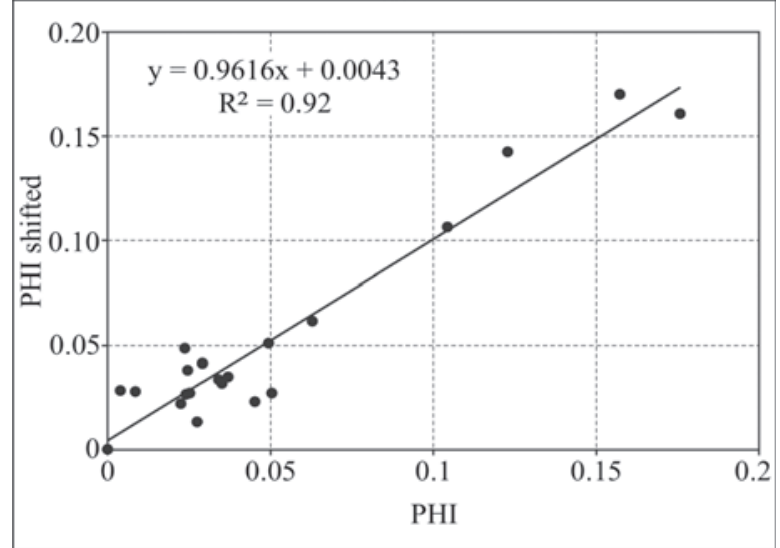

Fig. 6. Correlation between total porosity shifted in depth and porosity from the comprehensive interpretation

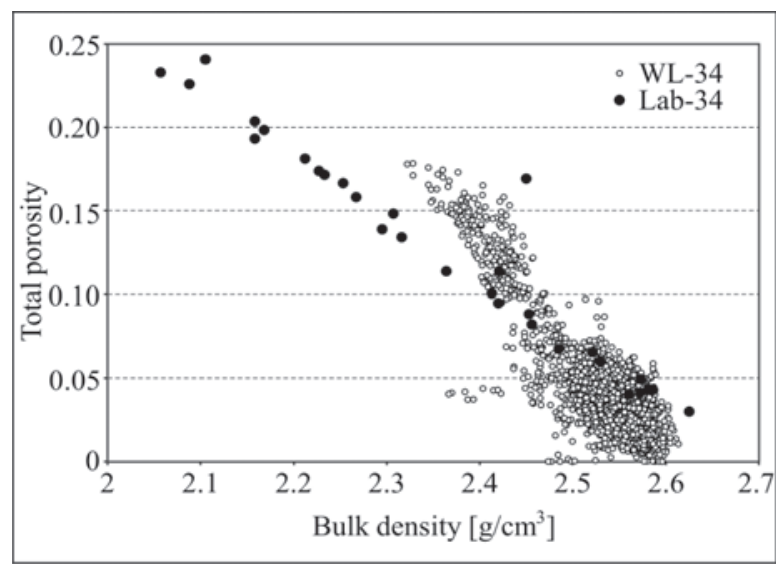

Fig. 7. Relationship between total porosity vs. bulk density (laboratory data and well logging)

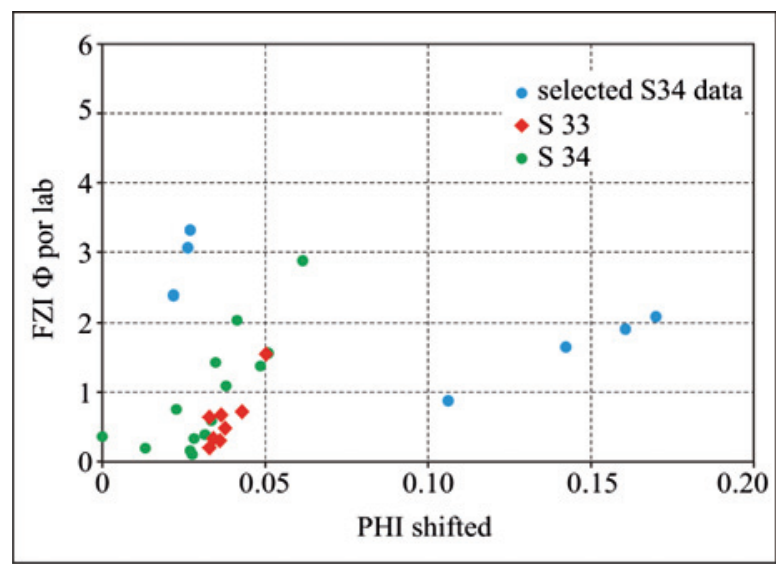

Fig. 8. Relationship between FZI calculated from $\Phi$ por lab and PHI shifted

PHI shift in depth was in the frame of several centimeters taking into account vertical resulution of the used logs not higher than $30 \mathrm{~cm}$. Shifted values of porosity PHI were the basis for correlation with FZI in wells S 33k and S 34 (Fig. 8). Data 
from well S34 consisted of two subgroup, the first one was characterized by low PHI (0.022-0.0271) and high FZI (2.39-3.32), the second represented points of high porosity $(0.1063-0.17)$ and relatively low flow zone indicator (0.87-2.08). Looking at the primary data, authors recognized that in the first subgroup there were data of high permeability (51.22-148.29 mD) and relatively low PHI (0.0220.0271 ), in the second subgroup there are data of similar permeability $(30.47-84.89 \mathrm{mD})$ but high PHI (0.1063-0.17). The presented results pointed out once more that more information is possible to be obtained from analysis of various combined parameters.

\section{FACIES DETERMINATION FROM WELL LOGGING}

The idea of using wireline logs as sedimentological tools is based on the shape of GR and SP or other curves associated with facies and environment of deposition (Bingjian et al. 2011). Facies variation in the geological profile is a consequence of structurally generated topography that controls sediment pathways and ultimately determined facies distribution. Each depositional environment grades laterally into other environments what means facies change when analyzing rock record (Galloway 1989, Porębski 1996, Reading 1996). Facies are normally identified in cores and classified on the basis of microscopic and small scale features such as lithology, grain size, texture, sedimentary structure, color and fossil type. However, facies data are only available in few cored wells. Conventional logging is usually available in all wells but it only provides information at a medium scale. These data can be calibrated with geological facies to generate electrofacies used for prediction of the reservoir property distribution (Samadi et al. 2006).

As porous and permeable reservoir-quality strata are often confined to the facies typical of high energy environment an understanding of the distribution and continuity of these facies can be important in understanding the reservoir parameters of size, geometry, zonal continuity and porosity distribution (Basham \& Dorfman 1983). Presently, depositional facies distribution is determined from geologic analysis of laboratory and well logging data.

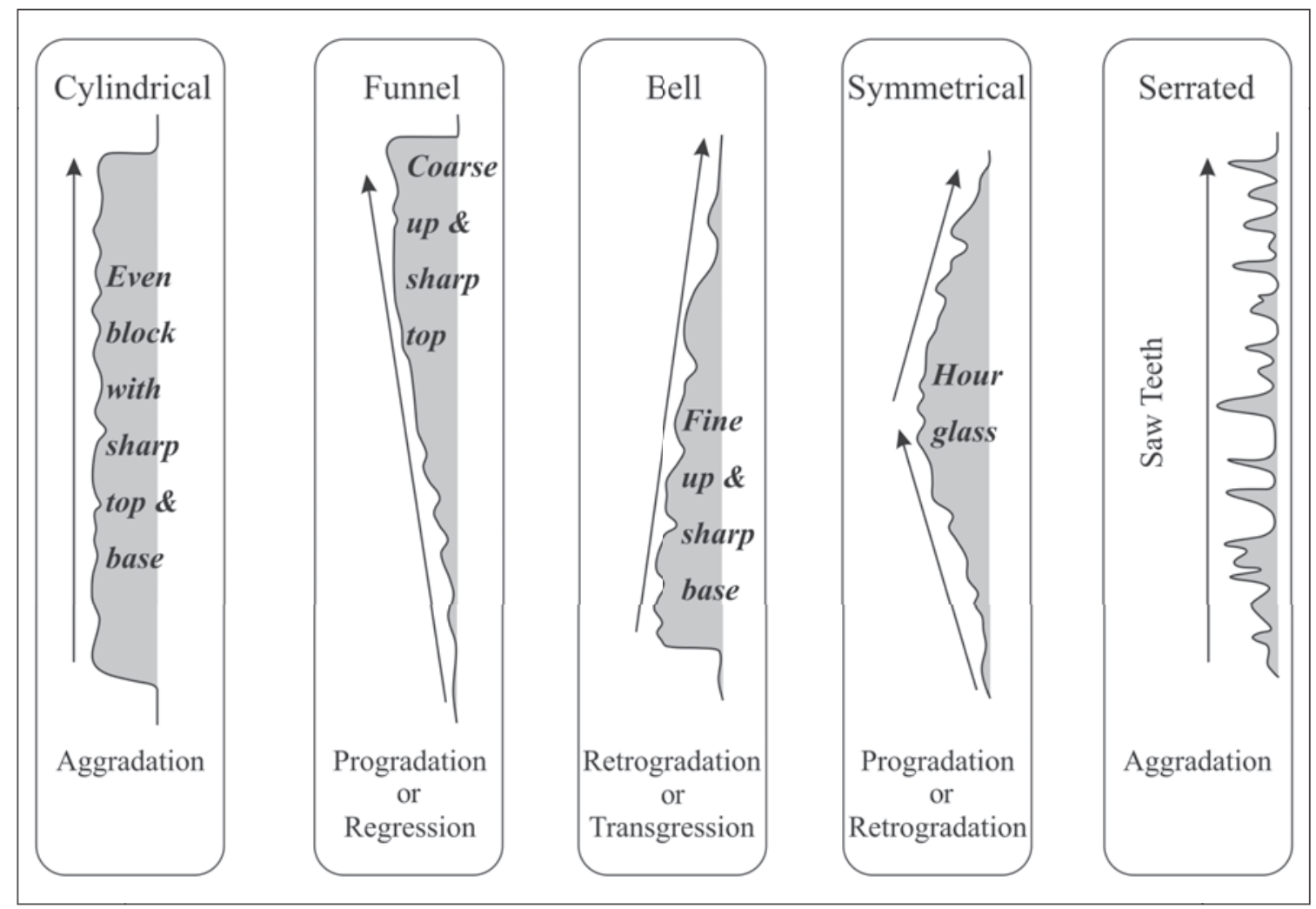

Fig. 9. GR/SP log shapes, nomenclature, environments of deposition (acc. to Catuneanu 2006) 
Different shape of GR can be interpreted as grain-size trends and by sedimentological association as facies successions. A decrease in GR values indicates an increase in grain size and small grains generally correspond to higher gamma ray values. An entire range of log shapes has been described in the literature by many authors (Catuneanu 2006 and other positions therein) but the most commonly recurring patterns include blocky (cylindrical), jagged (irregular or serrated), bell shaped or fining-upward and "funnel shaped" or coarsening-upward (Fig. 9) (Catuneanu 2006). The sedimentological implication of this relationship leads to a direct correlation between facies and logs.

\section{Facies determination in S 33k and S 34 wells}

Facies related to lithology and sedimentary environment were determined in S 33k and S 34 wells on the basis of GR and PHI logs. Analysis of the shape of anomalies was the basis to identify parasequences. Parasequence was defined as a small scale succession or beds set bounded by flooding surfaces (Porębski 1996 and other positions therein). Sediments in parasequence were related to facies constructed in progressively changed sea level. Thickness of parasequence was variable, from less than one to several meters.

The Autochthonous Miocene sediments were observed at different depths in S 33k and S 34 wells. The results of the comprehensive interpretation of well logs enabled presentation of the succession of sediments. Similar series were observed in both wells (Tab. 3).

GRC [API] curves and their mirror reflections (1-GRC [API]) are presented in Figure 10 in both wells in depth sections related to the Miocene succession. Similarity in the anomalies shape is distinctly visible. Regularly bedded series of sandstones, mudstones and claystones constructed parasequencies observed in the upper part of geological profiles in both wells (Fig. 11A, C for S 33k and S 34). In the lower part of the profiles where fine grained siliciclastics sediments converted to heterolithes occurred, the shapes of GRC anomalies did not reveal succession of parasequences as distinctly as in the upper part. Domination of mudstones and claystones in those parts of profiles is visible from the highest GRC values (Figs 10 and 11). GRC histogram in the Miocene interval in $\mathrm{S} 33 \mathrm{k}$ well also confirmed two distinct parts of the GRC data sets related to sandstones, shaly sandstones (GRC $<80 \mathrm{API})$, mudstones and claystones (GRC > 80 API) (Fig. 12). Generally, GRC histograms in both wells in the Miocene sediments showed two-modal character. They were the basis to draw the cutoff lines between more sandy (sandstone) deposits and more shaly (mudstone/ claystone) deposits. Histograms illustrated also the range of parameters. GRC anomalies ranged between 30-90 API in S34 and 55-125 API in S 33k what meant that the Miocene sediments in S 33k are more shaly than in S 34 well.

Table 3

Results of the lithostratigraphic division of the Miocene succession in wells S 33k and S34 on the basis of well logs (acc. to Reports on well logging data of well S 33k and well S 34 by Geofizyka Kraków SA)

\begin{tabular}{|c|c|l|}
\hline Well & Depth $[\mathbf{m}]$ & \multicolumn{1}{|c|}{ Description } \\
\hline \multirow{4}{*}{ S 33k } & $1350.0-2899.5$ & Miocene succession \\
\cline { 2 - 3 } & $1350-1600$ & thick-bedded sandstone series, higher energy environment (Allochthonous Miocene) \\
\cline { 2 - 3 } & $1600-2068$ & regularly alternated sandstone, mudstone, claystone series \\
\cline { 2 - 3 } & $2068-2790$ & fine-grained sediments and heterolithes of low energy environment heterolithes \\
\cline { 2 - 3 } & $2790-2858$ & fine-grained sediments, highly tectonically distorted \\
\hline \multirow{4}{*}{} & $951-2956.5$ & Miocene succession \\
\cline { 2 - 3 } & $951-979$ & shales (Allochthonous Miocene) \\
\cline { 2 - 3 } & $979-1448$ & siliciclastic series \\
\cline { 2 - 3 } & $1448-2134$ & alternated sandstone, mudstone, claystone series \\
\cline { 2 - 3 } & $2134-2928$ & siliciclastic fine-grained sediments locally turned into heterolithes \\
\cline { 2 - 3 } & $2928-2958$ & evaporates \\
\hline
\end{tabular}




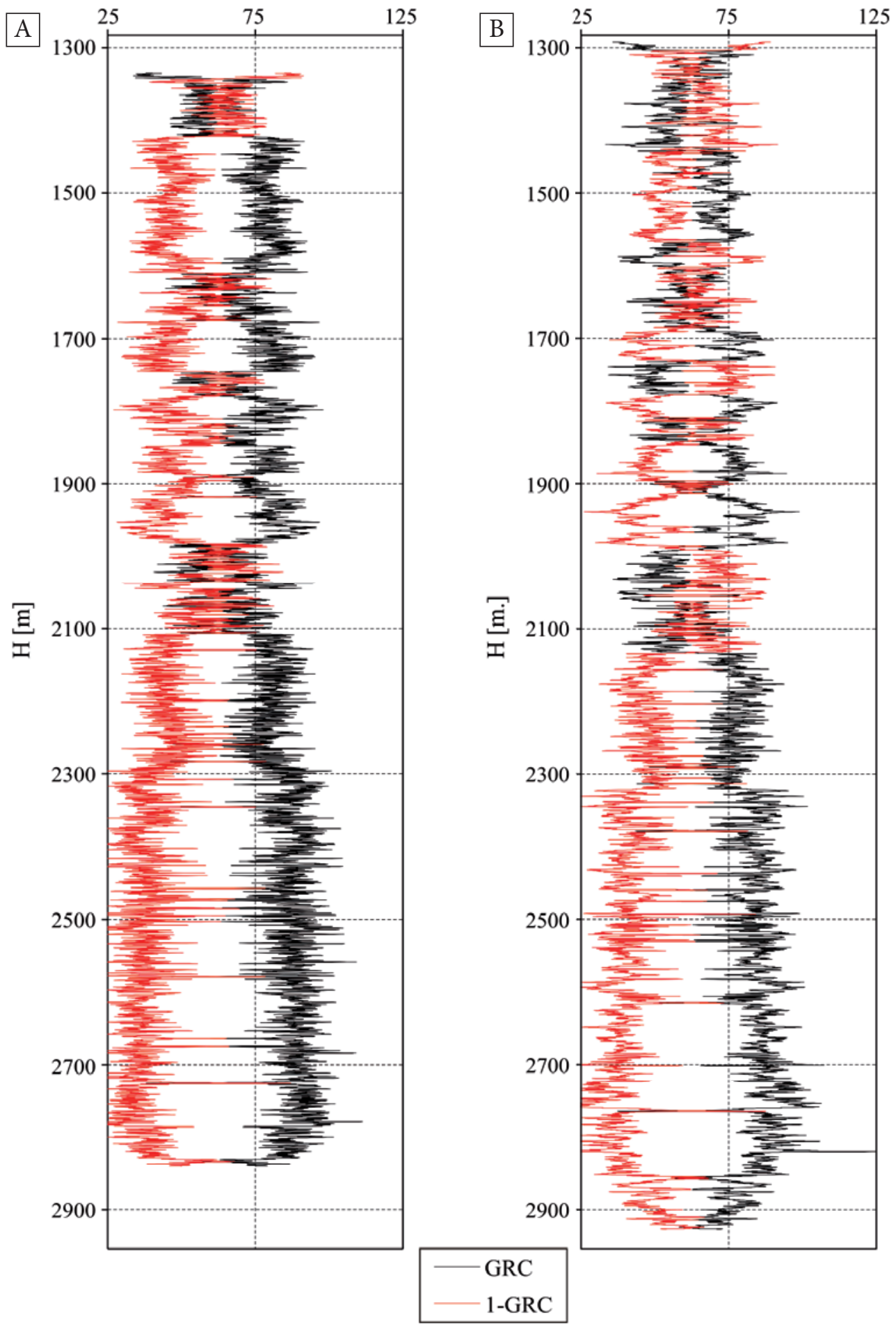

Fig. 10. GRC anomalies in $S 33 k$ well (A) and $S 34$ well (B)

Characteristic changes in GRC anomalies in the upper and lower sections of the discussed Miocene profile are more distinctly visible in Figure 11.

The goal of the paper was to show the relationship between facies and reservoir properties of the Miocene sediments. Detailed identification of the parts of the geological profiles related to regression and transgression sedimentary environments was performed in the cored sections of geological profiles in discussed wells. An example of regressive set of parasequences in the cored interval of the well S 34 was identified on the basis of GRC and PHI curves (Fig. 13). 


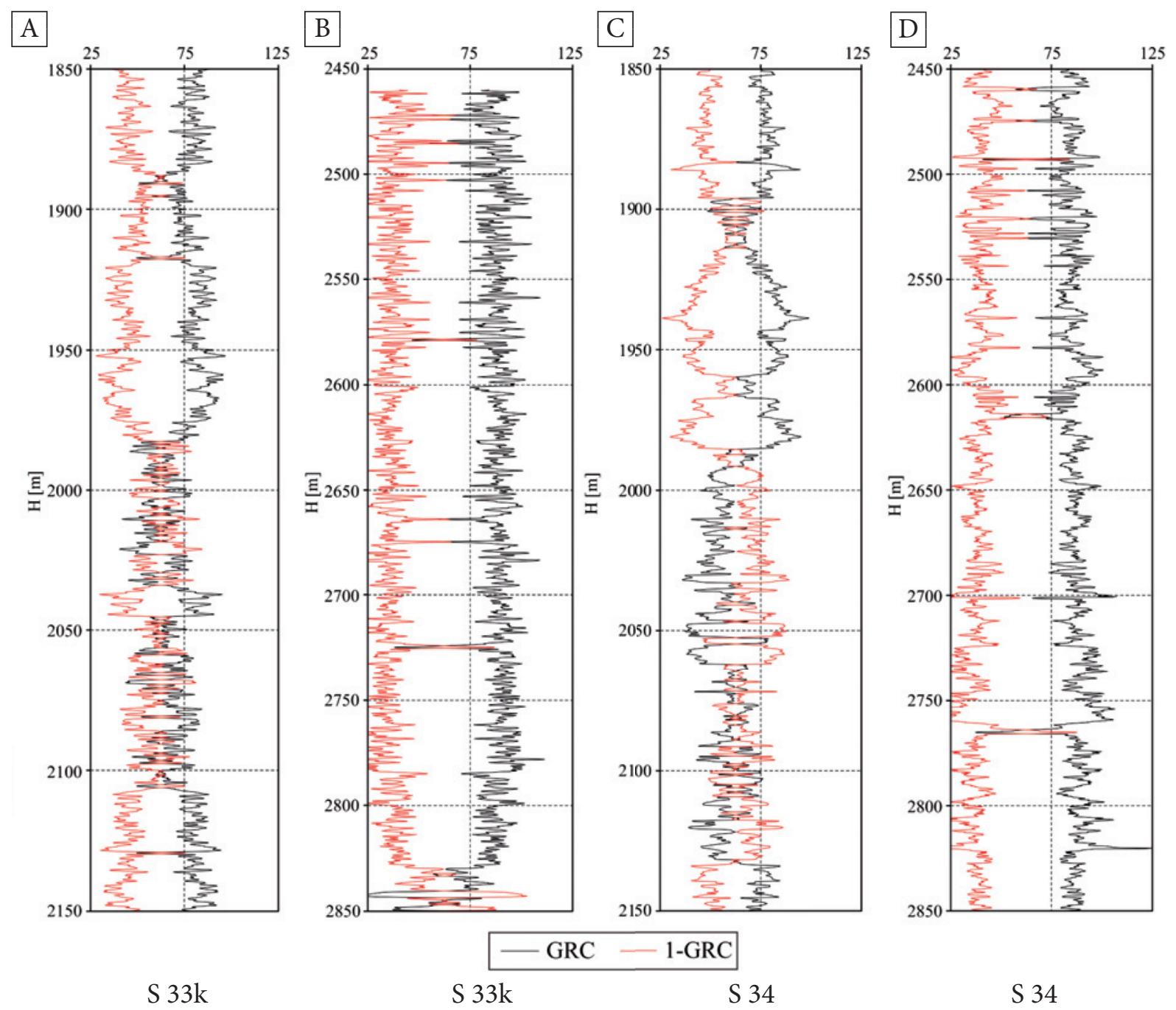

Fig. 11. Comparison of characteristic shape of GRC anomalies related to different sedimentation environment in the upper and lower parts of the Miocene succession in $S 33 k(A, B)$ and $S 34(C, D)$ wells

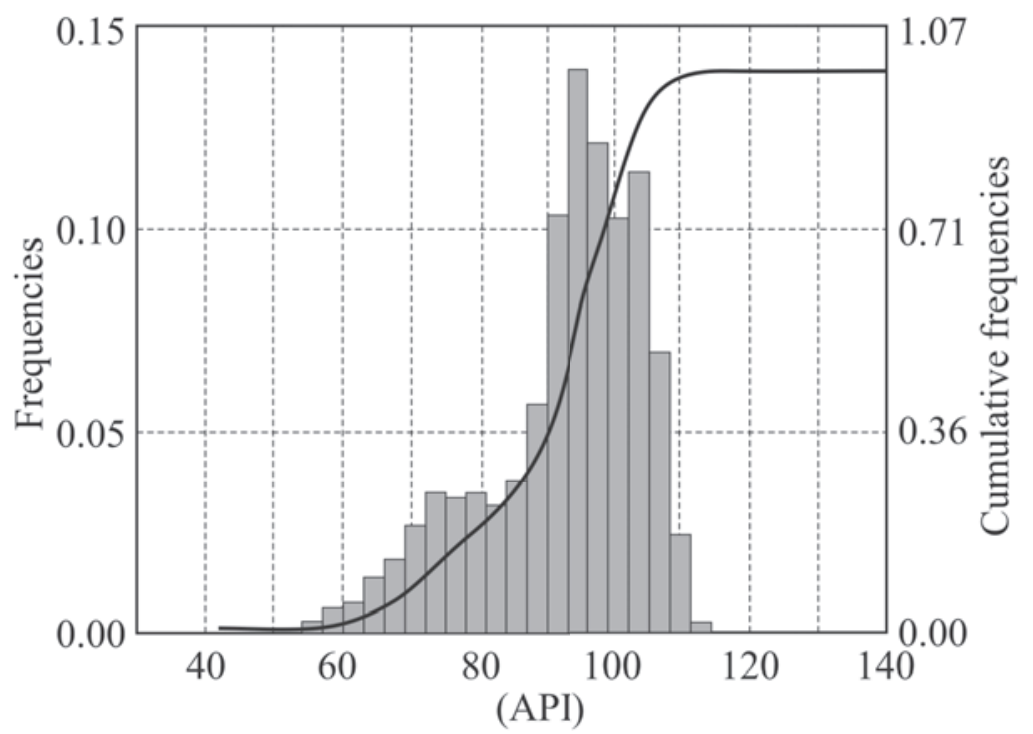

Fig. 12. GRC histogram in well S 33k in depth section 1335-2860 m 


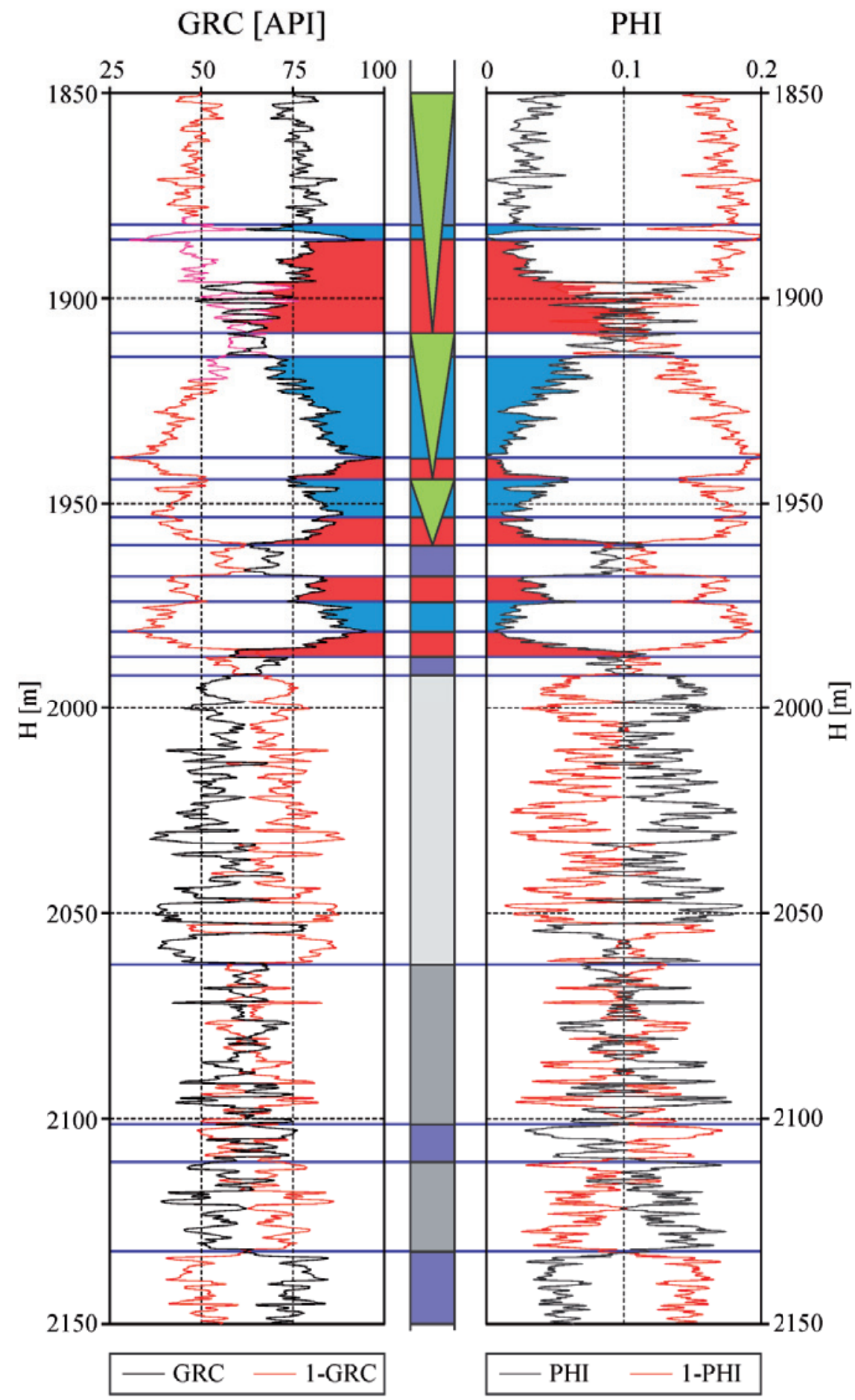

Fig. 13. Set of regressive parasequences (green arrows) identified in the $S 34$ well in the cored interval; black curves - GR and PHI, respectively, red curves - mirror reflection, in red-transgression, in blue - regression, various shade of gray - aggradation

Shape and sequence of GRC and PHI anomalies were the basis for parasequences determination. Including PHI log into facies determination was a connection between lithology and sedimentary environment and porosity as a representative of reservoir properties.
Cut off values determined form GRC histograms for S 33k and S 34 wells (80 and 65 API, respectively) were used for detailed presentation of facies determined in the Miocene succession in both wells (Fig. 14). Preprocessing of GRC anomalies using cut off values made easier facies patterns recognition. 

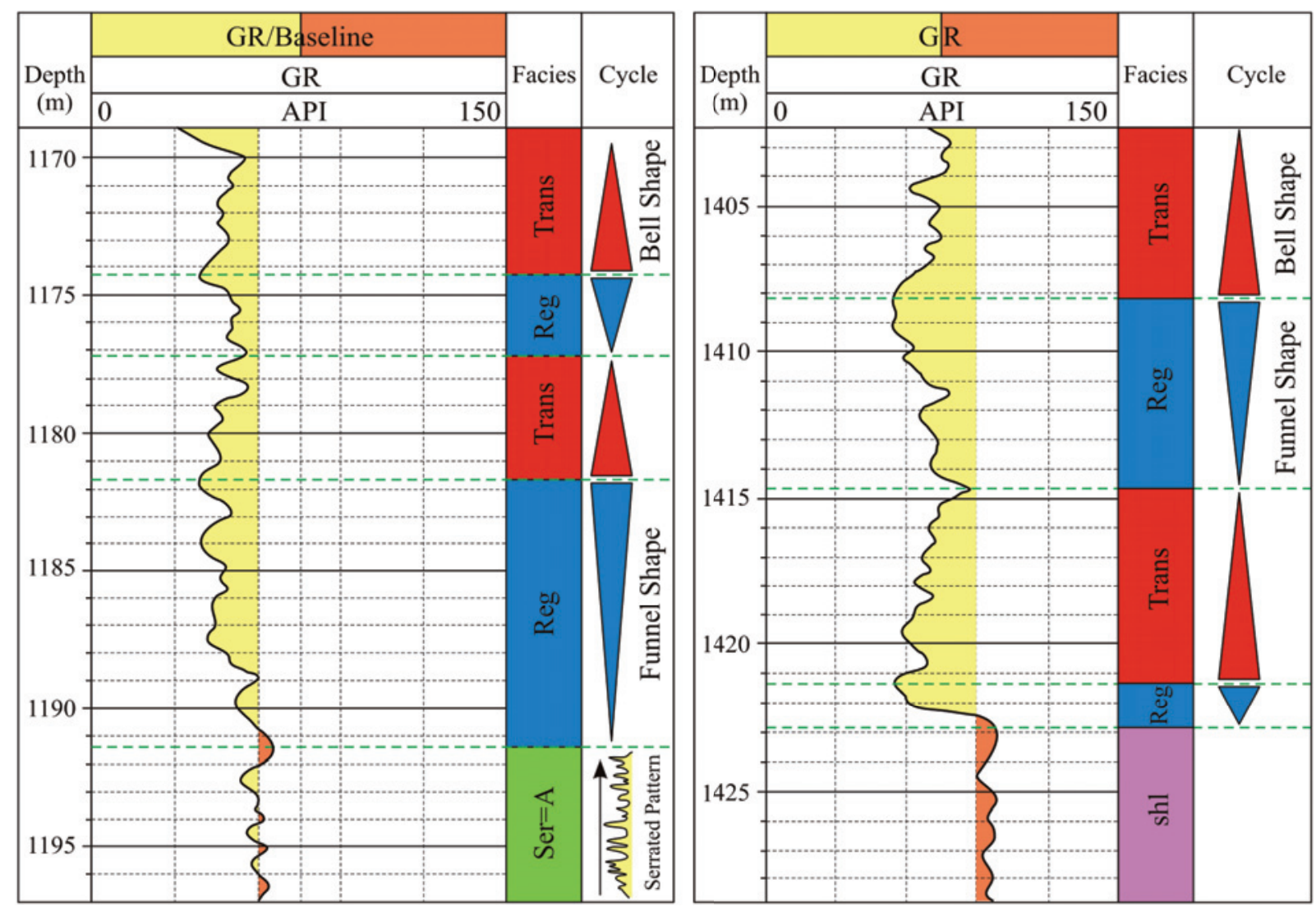

Fig. 14. Examples of facies determination using GR curves modified with cut off value; S 34 well

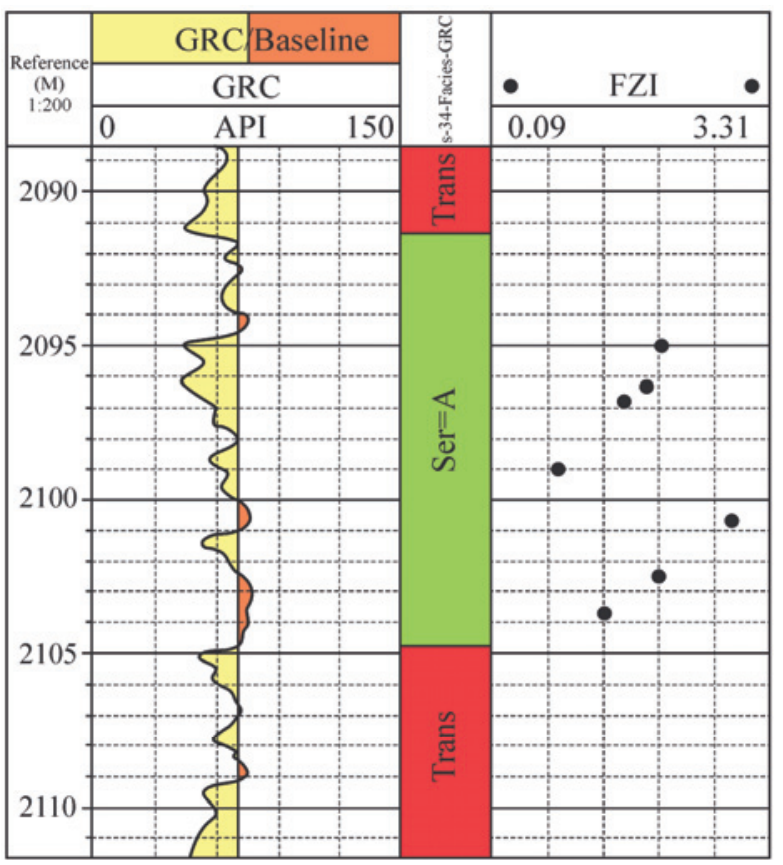

Fig. 15. Facies on the basis of the preprocessed GRC curve with FZI sequence in $S 34$ well

Reservoir properties and hydraulic ability represented by FZI and facies were combined to provide more information about sediments. In S 34 well in the depth section 2095.02-2099.00 m, funnel shape GRC anomaly in regression system and a sequence of FZI values and PHI values which correlated well with FZI were observed (Figs 15 and 8). In other depth sections in S 34 well similar relationships PHI vs. FZI, i.e. increase of FZI with PHI increase were also observed. In most cases, such relationships were identified in funnel shape GRC anomaly and regression system. Presented connections between factors determined from various sources (PHI - well logging), FZI - laboratory measurements and facies (GR/GRC - well logging) made up additional information useful in the combined interpretation of data obtained in different scales.

\section{CLOSING REMARKS}

Combining reservoir properties with facies distribution in the Miocene formation in the Carpathian Foredeep was aimed to enhanced information about porous and permeable parts of the thin-bedded sandy-shaly formation, especially to find gas traps. Flow Zone Indicator calculated on the basis 
of laboratory determined porosity and permeability was correlated with facies identified on the basis of gamma ray $\log$ and porosity $\log$. Point information from laboratory was combined with $1 \mathrm{D}$ data from well logging. Conclusion that good hydraulic abilities correlate with regression set of facies determined in the cored sections of wells can be extrapolated to others sections of geological profile on the basis of facies identification from well logs. Thanks to it, a kind of scaling data from two separate sources was done.

Authors are grateful POGC SA Warsaw, Poland to allow using the data available for realization scientific project NCN no N525 254040. Laboratory measurements were realized by Oil and Gas Institute, Krakow, Poland. TechLog program (Schlumberger) was used with reference to the AGH UST University Grant. Paper was partially realized within the confines of statutory project no 11.11.140 769 of the Faculty of Geology Geophysics Environmental Protection, Department of Geophysics AGH UST, Krakow, Poland, $2014 \mathrm{yr}$. Authors are grateful Editor and Reviewers to make the paper more easy readable.

\section{REFERENCES}

Amaefule J.O., Altunbay M., Tiab D., Kersey D.G. \& Keelan D.K., 1993. Enhanced reservoir description: using core and $\log$ data to identify hydraulic (flow) units and predict permeability in uncored intervals/wells. SPE Annual Technical Conference and Exhibition, 3-6 October, Houston, Texas, SPE 26436, 205-220.

Bała M., Jarzyna J. \& Mortimer Z., 2012. Statistical analysis of petrophysical parameters of Middle Miocene rocks from the Polish Carpathian Foredeep. Geological Quarterly, 56, 4, 665-680.

Basham W.H.M. \& Dorfman M.H., 1983. Facies characterization of carbonates by use of well logs. Sligo Formation (Lower Cretaceous). South Texas. Transactions of the SPWLA Twenty-Fourth Annual Logging Symposium, SPWLA 1983, 24, 79-96.
Bingjian Li, Peace G., The R., Maykho S. \& Farag S., 2011. Interpreting electro-facies and fractures for an Oligocene sandstone reservoir using borehole images acquired in synthetic drilling fluids with full core calibration: a case study from Songkhla Basin, Thailand. International Petroleum Technology Conference, 15-17 November, Bangkok, Thailand, IPTC 15089.

Carman P.C., 1937. Fluid flow through granular beds. Transactions of the Institutions of Chemical Engineers, 15, 150-167.

Catuneanu O., 2006. Principles of Sequence Stratigraphy. Elsevier, Amsterdam, Boston, Heidelberg.

Galloway W.E., 1989. Genetic stratigraphic sequences in basin analysis. I: Architecture and genesis of flooding-surface bounded depositional units. American Association of Petroleum Geologists Bulletin, 73, 125-142.

Ha Quang Man, Jarzyna J., 2013. Integration of core, well logging and 2D seismic data to improve a reservoir rock model: a case study of gas accumulation in the NE Polish Carpathian Foredeep. Geological Quarterly, 57, 2, 289-306.

Kozeny J., 1927. Über kapillare Leitung des Wassers im Boden. Sitzungsberichte der Kaiserlichen Akademie der Wissenschaften, Wien, 136, 271-306.

Mastalerz K., Wysocka A., Krzywiec P., Kasiński J., Aleksandrowski P., Papiernik B., Ryzner-Siupik B. \& Siupik J., 2006. Sukcesja osadowa miocenu w rejonie zrębu Ryszkowej Woli (obszar Sieniawa - Rudka), zapadlisko przedkarpackie: wyniki facjalnej i stratygraficznej interpretacji danych wiertniczych oraz sejsmiki 3D. Przeglad Geologiczny, 54, 4, 333-342 [with English summary].

Myśliwiec M., 2004a. Mioceńskie skały zbiornikowe zapadliska przedkarpackiego. Przegląd Geologiczny, 52, 7, 581-592 [with English summary].

Myśliwiec M., 2004b. Typy pułapek gazu ziemnego i strefowość występowania ich złóż w osadach wschodniej części zapadliska przedkapackiego. Przegląd Geologiczny, 52, 8/1, 657-664 [with English summary].

Porębski S., 1996. Podstawy stratygrafii sekwencji w osadach klastycznych. Przegląd Geologiczny, 44, 996-1005 [with English summary].

Reading H.G. (Ed.), 1996. Sedimentary Environments. Processes, Facies and Stratigraphy. Blackwell Science, Oxford.

Samadi M.H., Shahalipour R., Mohammadlou M.H., 2006. Integrated facies and microfacies modelling using both wireline logs and core data in heterogenic reservoirs. SPWLA 47th Annual Logging Symposium, 4-7 June, Veracruz, Mexico, SPWLA-2006-JJ. 